\title{
Rejuvenating Public-Private Partnerships (PPPs) in Asia
}

\author{
Author - Dr (Mrs) Satinder Bhatia \\ Professor of Finance, Indian Institute of Foreign Trade \\ B-21, Qutab Institutional Area, New Delhi - 110016 India \\ E-mail: satinderbhatia@iift.ac.in \\ Telephone Number: 91-11-26964742 \\ Fax Number: 91-11-26859520
}

\begin{abstract}
Infrastructure-building has become a focus area in Asia as targeted GDP growth rates climb higher. Selection of projects as PPP projects or pure public sector projects has to be done carefully comparing costs and benefits under both scenarios. Such an approach (value for money) is common in the UK and Australia which have considerable experience in PPP projects.
\end{abstract}

Keywords: Functional Cost Breakdown, PPP projects, Public Sector Comparator, Life Cycle Costing, Value for Money

\section{Introduction - Need for PPPs}

Public-Private Partnerships (PPPs) have become increasingly popular around the globe and have served as a major route for the private sector to own, operate and, thereby, assume risks in what was assumed to be exclusively public sector assets. Just like funding for PPP projects comes from both the public and the private sector, risks of the project have also to be carefully divided between the private and the public sector. The basis of the division will have to be the risk-handling and managing competence. This aspect itself, if well-attended, will translate into better value for money for consumers of services produced by PPP projects. If PPP projects are looked at as merely a way to overcome fiscal constraints, the likelihood of their poor implementation and/or complete failure is definitely very high. Before deciding on the type of PPP project; therefore, a basic question has to be answered:

- Why do we need the project to be designed as a PPP project? Has the analysis taken into account the alternatives that are clearly available - the alternative that this project could completely be in the public or the private sector? If so,

- What are the estimates of costs and benefits if this project were to be totally in the public sector?

- What are the estimates of costs and benefits if this project were to be totally in the private sector - more like the PFI or Private Finance Initiative in UK. While one firm may not be in a position to assume risks of a long-term project with high capital intensity, there could be different consortiums of private players coming together for the purpose of executing the project just like consortiums are formed for funding a project. The consortium then sells the services produced to the government.

\section{Using the Comparator Approach}

European nations, and UK in particular, have been at the forefront of publicizing and using the comparator approach wherein the costs and benefits of a PPP project are compared with costs and benefits of the project being totally a public sector project. This kind of analysis overrides the earlier phase wherein most projects were awarded on BOOT or BOO terms without analysis by a comparator approach. The key driver of these projects was access to private capital and transfer of near full project risks to the private sector. The form of PPP then usually emphasized both construction and maintenance by the private sector as that would minimize bad quality construction risks as well. Some governments outrightly preferred the DBFO model - Design, Build, Finance and Operate model to minimize risks in each phase of the project. In return, the governments would either give a capital grant or tax exemptions or guaranteed rate to return to the private sector. Similarly, under a Fixed Price contract with the private party, the risks of procurement costs going up are borne entirely by the private sector leaving the public sector to better regulation and providing good business climate for private entrepreneurs.

The drive for 'value for money' has underpinned the second phase of PPP projects in both UK and Australia. As made clear by the Private Finance Panel (PFI) of UK, there are two fundamental requirements for a PFI project:

i) value for money must be demonstrated for any expenditure by the public sector; and

ii) the private sector must genuinely assume risk.

Hence, measurement of value for money becomes extremely crucial and the benchmarks set for comparison (public sector comparator), thereby, assume huge significance. Any error in the estimates for the PSC will translate into erroneous value for money estimates. An evaluation of value for money may be depicted as follows: 


\section{Value for Money Evaluation}

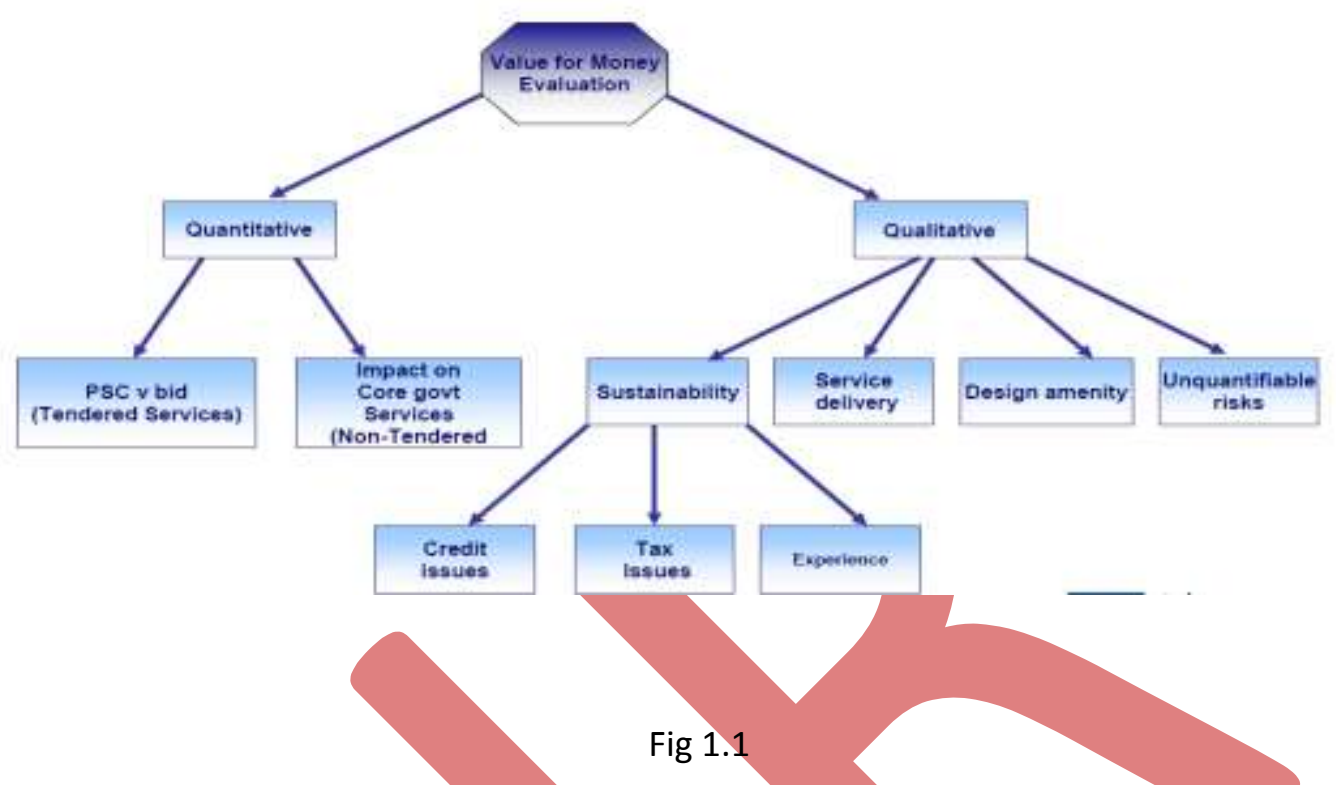

Source: Presentation of State Government of Victoria, Department of Treasury \& Finance at APEC Conference, 2007

As is evident in the above figure, both qualitative and quantitative factors are taken into account for 'value for money' evaluation. The proposed transfer of risk in any PFI project is subject to external audit and, subsequently, ratification by central government (Ball et al., 2000). On the surface, the principle behind risk transfer would appear to be fairly straightforward and is a practice commonly used in contracts between private sector companies. In PFI contracts, however, the situation relating to risk transfer has been one of 'clearly a continuing level of uncertainty' (Broadbent \& McLaughlin, 1999, p. 106). The House of Commons Treasury Select Committee (2000) inquiry into PFI emphasized that risk transfer must be clearly identified, so that government bodies can set out clearly the risks that are being transferred. Risk is now a commercial product that is identified, priced and responsibility legally attributed (Centre for Public Services, 2001).

\section{How to Add Value: The Application of Value Management}

Good project management is at the base of adding value in PPP projects. Project management encompasses several areas such as scope management, cost management, quality management, risk management, procurement management, time management, human resources management, communications management and project integration management. Each of these areas involve key processes such as initiating, planning, executing, monitoring \& controlling and closing. All the PPP partners have to sit together and assess which partner has better capacity to undertake which process in which knowledge area. The idea is to be able to define and achieve the objectives with the minimum use of resources. The different perspective that results from the adoption of this approach encourages the development of more creative solutions to problems, potentially eliminating many causes of poor value. Value on projects can potentially be undermined by many factors, the most significant being poor project definition. The need to define relevant client requirements unambiguously at an early stage has become increasingly critical as the speed of projects gives less opportunity for a comprehensive, iterative briefing process. This issue is particularly important on projects with a wide range of stakeholders whose diverse requirements will need reconciling and prioritising as part of a briefing process.

Value management differs from conventional cost reduction in three ways: it aims to achieve the best balance between time, cost and quality; it is a multidisciplinary process that involves the whole project team; and its decisionmaking process is explicit, accountable and clearly linked to project objectives. However, value management can be a very effective tool for reducing costs while ensuring that the spirit and quality of a project's design is retained.

The agreed project objectives provide the decision-making framework within which cost-effective design solutions are produced. Functions that need to be provided to achieve the objectives are identified, and the project design is developed to focus on these requirements, thereby avoiding unnecessary cost. This process enables clients to appreciate the value of design and encourages the development of high-quality architectural solutions where these match the client's needs. 
Value for money is a key driver in public-private partnerships. Value for money does not simply equate to selecting the cheapest bid or lowest price for an asset; it means opting for the best long-term solution for service delivery. It involves analyzing the total long-term costs (life cycle costs) of service delivery and evaluating the concomitant benefits to the public at large. When compared to a public sector approach, incremental benefits of PPPs may accrue from: speedier implementation of infrastructure projects, better service and coverage, life cycle focus of service delivery/reduced life cycle (long-term) costs, improved efficiency and innovation and risk sharing designed to create incentives to succeed. Value for money is a key driver in public-private partnerships. Value for money does not simply equate to selecting the cheapest bid or lowest price for an asset; it means opting for the best long-term solution for service delivery.

Life-cycle costing, as opposed to costing during construction stage, then, becomes extremely relevant for project appraisal. It is in this context that DBFO projects are supposed to spur innovation for minimizing costs during the design, building, financing and operating stages. This bundling of services motivates the bidder to pay good attention to quality parameters in the design and building stages so as to minimize costs to be incurred during the operating stage. In that sense, the risks of poor construction are transferred from the public authority to the private partner. In fact, a lot of value addition has to do with the ability to avoid the risks of poor performance at every stage of construction. In the longer run, DBFO contracts will be seen as the public sector purchasing access to and use of service assets, rather than the procurement of a capital asset. At present most involve the latter. In theory, the contractor should take responsibility for investing in capital assets, financing that investment and managing the facilities for the local authority. The risk is associated with the commitment to supply the service over an extended period for a specified level of payment. The risk is transferred to the contractor. In theory no local authority should give undertakings or guarantees in respect of contractor obligations and liabilities. If it were to do so, it would simply retain the commercial risk that should be transferred.

Davis Langdon \& Everest (June 2000) gave an example of this in the construction of a building.

\section{Applying value management through the life of a project}

athos

Conaept

Fexiblity

Deslgn

Constudton

LFe
Ob]jottive

Gethe nitt propt

Beted te bet odtor

Achiscurtelbutenes

Optmle apph-che'h ellidency

Cothns improtent

\section{Tsohriques}

Bectrroting, tuncton arayst, He-gcle coding

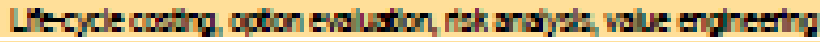

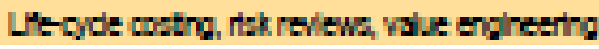

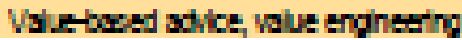

Lhoyde cot compartans, ameja, valueteng heting ooenton:

Source:http://www.davislangdon.com/upload/StaticFiles/EME\%20Publications/CostModels/ValueForMoney_CM_30Jun00. pdf

Davis Langdon \& Everest (June 2000) in their study found better results in terms of value addition when they did activity-wise cost breakdown rather than a traditional cost breakdown. The cost structure, in their study, under both circumstances, was presented as follows:

\section{Construction cost breakdown for bar/restaurant}




Fig. 1.3

\section{Functional cost breakdown for bar/restaurant}

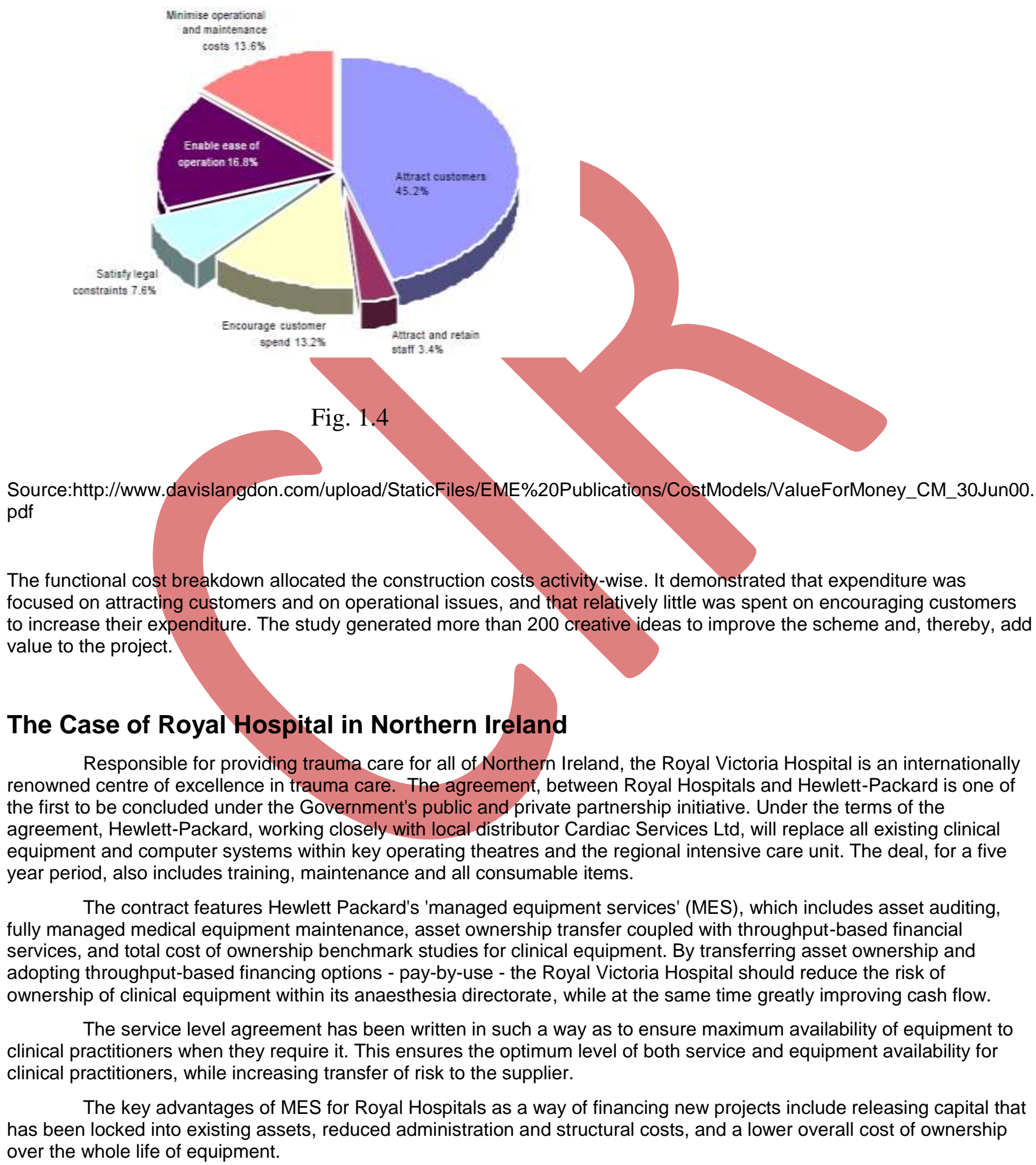
over the whole life of equipment. 


\section{Research on Value for Money (VFM) in Selected Projects}

Since India is now embarking on the concept of Value for Money as stated in the Approach Paper to PPPs dated Feb 2010, it may be good to see the results of selected projects including their Value for Money measurements. The following is a list compiled by Graeme A. Hodge and CarstenGreve (March 2009). In all these studies, it is evident that projects that had not demonstrated value for money ultimately could not produce desired results.

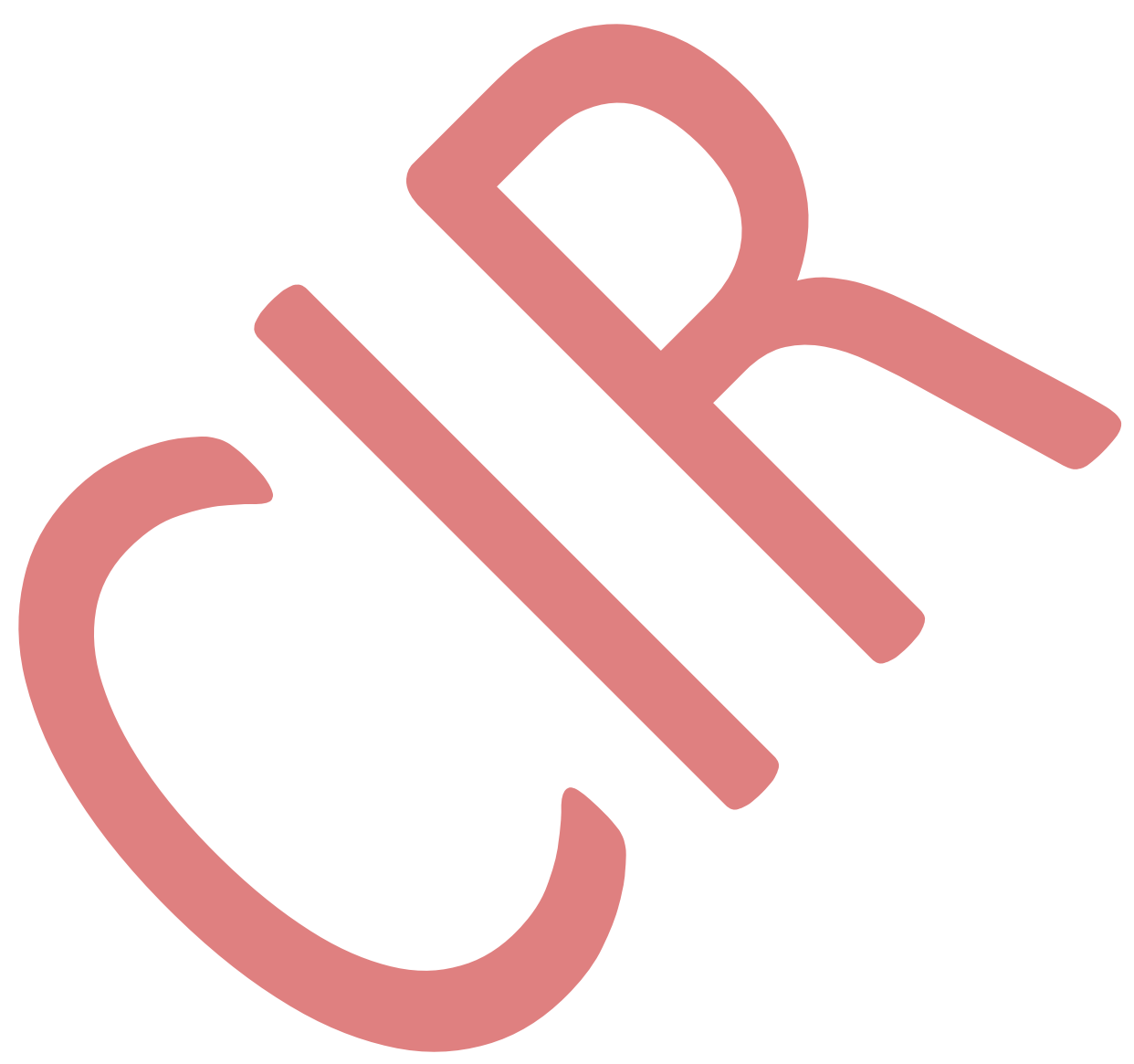


Table 1: Selected PPP evaluations over the past decade

\begin{tabular}{|c|c|c|c|c|c|}
\hline Study & Sample/Cases & Country & $\begin{array}{l}\text { Type of } \\
\text { publication }\end{array}$ & $\begin{array}{l}\text { Better } \\
\text { vfM? }\end{array}$ & Comments/Conclusions \\
\hline $\begin{array}{l}\text { Bloomfield et al. } \\
\text { (1998) }\end{array}$ & $\begin{array}{l}\text { A Massachusetts } \\
\text { correctional facility }\end{array}$ & United States & Case study & No & $\begin{array}{l}\text { - } 7.4 \% \text { more expensive through P3 lease purchasing } \\
\text { - 'inflated sales pitches' camouflaged real costs and risks to } \\
\text { the public, and the project was 'wasteful and risky' }\end{array}$ \\
\hline $\begin{array}{l}\text { Arthur Andersen \& } \\
\text { LSE Enterprise (2000) }\end{array}$ & $\begin{array}{l}29 \text { business cases } \\
\text { analysed }\end{array}$ & United Kingdom & Initial evaluation & Yes & $\begin{array}{l}\text { - } 17 \% \text { cost savings estimated against the PSC } \\
\text { - risk transfer accounted for } 61 \% \text { of forecast savings }\end{array}$ \\
\hline Savas (2000, p. 240) & General observations & United States & Literature review & Yes & $\begin{array}{l}\text { - [the private sector through PPPs] build more quickly and } \\
\text { more cost effectively than governments usually can .... }\end{array}$ \\
\hline $\begin{array}{l}\text { National Audit } \\
\text { Office (2000) }\end{array}$ & $\begin{array}{l}7 \text { business cases from } \\
\text { NAO }(2000)\end{array}$ & United Kingdom & Business cases & Yes & - $10-20 \%$ cost savings estimated \\
\hline $\begin{array}{l}\text { Walker and Walker } \\
(2000, \text { p. 204) }\end{array}$ & $\begin{array}{l}\text { General observations } \\
\text { of Australian cases }\end{array}$ & Australia & Literature review & - & $\begin{array}{l}\text { - PPP infrastructure financing deals seen as 'misleading } \\
\text { accounting trickery' with eroded accountability to Parliament } \\
\text { and the public } \\
\text { - private project consortium real rates of return were up to } \\
10 \text { times those returns expected for the public }\end{array}$ \\
\hline $\begin{array}{l}\text { Teisman and Klijn } \\
(2001)\end{array}$ & General observations & 4 EU countries & $\begin{array}{l}\text { Review of strengths } \\
\text { and weaknesses }\end{array}$ & - & - PPPs have strengths and weaknesses \\
\hline DoT (2002) & $\begin{array}{l}250 \text { London } \\
\text { Underground } \\
\text { projects }(1997-2000)\end{array}$ & United Kingdom & Unknown & - & - Cost over-runs averaging $20 \%$ were found \\
\hline $\begin{array}{l}\text { Mott Macdonald } \\
(2002)\end{array}$ & $\begin{array}{l}39 \text { traditional projects } \\
\text { and } 11 \mathrm{PFI} \text { projects } \\
\text { selected }\end{array}$ & United Kingdom & $\begin{array}{l}\text { Multiple cases } \\
\text { reviewed }\end{array}$ & Yes & $\begin{array}{l}\text { - Traditional 'public' infrastructure provision arrangements } \\
\text { were on-time and on-budget } 30 \% \text { and } 27 \% \text { of the time, but } \\
\text { PFl-type partnerships were on-time and on-budget } 76 \% \text { and } \\
78 \% \text { of the time, respectively }\end{array}$ \\
\hline Pollock et al. (2002) & $\begin{array}{l}3 \text { NHS hospitals } \\
\text { and } 8 \text { trusts }\end{array}$ & United Kingdom & $\begin{array}{l}\text { Review and } \\
\text { re-analysis }\end{array}$ & No & - The PFl justification is a 'sleight of hand' \\
\hline Pollitt (2002) & 10 major $\mathrm{PFl}$ cases & United Kingdom & $\begin{array}{l}\text { Review of National } \\
\text { Audit Office cases }\end{array}$ & Yes & $\begin{array}{l}\text { - the best deal was probably obtained in every case, and good } \\
\text { value for money was probably achieved in } 8 \text { of the } 10 \text { cases }\end{array}$ \\
\hline $\begin{array}{l}\text { Audit Commission } \\
\text { (2003) }\end{array}$ & $\begin{array}{l}10 \text { traditional and } \\
8 \mathrm{PF} \text { schools were } \\
\text { compared }\end{array}$ & Scotland & Audit report & No & $\begin{array}{l}\text { - We found no evidence that PFI projects delivered schools } \\
\text { more quickly than projects funded in more conventional } \\
\text { ways' } \\
\text { - 'The public sector comparator has lost the confidence of } \\
\text { many people... }\end{array}$ \\
\hline Greve (2003) & $\begin{array}{l}\text { Case study of Farum } \\
\text { Municipality }\end{array}$ & Denmark & Case analysis & No & $\begin{array}{l}\text { - PPP assessed as 'the most spectacular scandal in the history } \\
\text { of Danish Public Administration' } \\
\text { - It resulted in raised taxes for the citizens of Farum, higher } \\
\text { debt for citizens and a former mayor currently on trial in } \\
\text { the courts }\end{array}$ \\
\hline Fitzgerald (2004) & $\begin{array}{l}8 \text { PPP cases from } \\
\text { Victoria }\end{array}$ & Australia & $\begin{array}{l}\text { Report to } \\
\text { government }\end{array}$ & Uncertain & $\begin{array}{l}\text { - The superiority of the economic partnership mode over } \\
\text { traditional delivery mechanisms was dependent on the } \\
\text { discount rate adopted in the analysis } \\
\text { - Opposite conclusions were reached when using an } 8.65 \% \\
\text { discount rate at one extreme (where the PPP mechanism was } \\
9 \% \text { cheaper than traditional delivery) compared to an } \\
\text { evaluation adopting a } 5.7 \% \text { discount rate (where the PPP } \\
\text { mechanism was } 6 \% \text { more expensive) }\end{array}$ \\
\hline Edwards et al. (2004) & $\begin{array}{l}8 \text { cases from roads } \\
\text { and } 13 \text { hospital } \\
\text { case studies }\end{array}$ & United Kingdom & $\begin{array}{l}\text { Case reviews and } \\
\text { interviews }\end{array}$ & No & $\begin{array}{l}\text { - Contracts reviewed } 3 \text { years in } \\
\text { - 'PFI is an expensive way of financing and delivering } \\
\text { public services...' } \\
\text { - 'the chief beneficiaries are the providers of finance and } \\
\text { some of .... the private sector service providers...' }\end{array}$ \\
\hline $\begin{array}{l}\text { Ghobadian et al. } \\
\text { (2004b, p. 300) }\end{array}$ & General observations & United Kingdom & Literature review & - & $\begin{array}{l}\text { - 'we have no firm evidence that the current PFls would } \\
\text { deliver on their long-term objectives...' }\end{array}$ \\
\hline $\begin{array}{l}\text { Grimsey and Lewis } \\
\text { (2004, pp. 81, 245) }\end{array}$ & $\begin{array}{l}\text { Selected global } \\
\text { observations } \\
\text { across several sectors }\end{array}$ & Several countries & Literature review & Yes & $\begin{array}{l}\text { - 'preliminary evidence does seem to indicate strongly that } \\
\text { PPPs offer one solution to the public procurement problem .... } \\
\text { - "there is not one "model" of a PPP...' }\end{array}$ \\
\hline Pollitt (2005) & $\begin{array}{l}\text { General observations of } \\
\text { UK cases plus } 5 \text { cases }\end{array}$ & United Kingdom & Literature review & Yes & - 'it seems difficult to avoid a positive overall assessment' \\
\hline Shaoul (2005) & $\begin{array}{l}\text { General observations } \\
\text { of UK cases }\end{array}$ & United Kingdom & Literature review & No & $\begin{array}{l}\text { - PFI has turned out to be very expensive with a lack of } \\
\text { accountability } \\
\text { - Suspects that PFI policies 'enrich the few at the expense } \\
\text { of the majority and for which no democratic mandate can } \\
\text { be secured' }\end{array}$ \\
\hline $\begin{array}{l}\text { Boardman et al. } \\
(2005, \text { p. } 186)\end{array}$ & $\begin{array}{l}5 \text { North America cases } \\
\text { covering roads, waste } \\
\text { management and } \\
\text { water desalination }\end{array}$ & $\begin{array}{l}\text { Canada and } \\
\text { United States }\end{array}$ & Case reviews & No & $\begin{array}{l}\text { - unless contracts both compensate the private sector for } \\
\text { risks and then ensure that they actually bear it, 'P3s will } \\
\text { not improve allocative efficiency' }\end{array}$ \\
\hline
\end{tabular}


Table 1: Continued

\begin{tabular}{|c|c|c|c|c|c|}
\hline Study & Sample/Cases & Country & $\begin{array}{l}\text { Type of } \\
\text { publication }\end{array}$ & $\begin{array}{l}\text { Better } \\
\text { vfM? }\end{array}$ & Comments/Conclusions \\
\hline Hodge (2005, p. 327) & $\begin{array}{l}\text { General observations } \\
\text { of UK cases plus } 3 \text { cases }\end{array}$ & Australia & Literature review & Uncertain & $\begin{array}{l}\text { - There have been no rigorous and transparent evaluations } \\
\text { of all Australian PPPs } \\
\text { - The few available assessments suggest mixed performance } \\
\text { to date } \\
\text { - Government has moved away from its traditional stewardship }\end{array}$ \\
\hline
\end{tabular}

- Government has moved away from its traditional stewardship conflicts of interest (as advocate, developer, steward, elected representative, regulator, contract signatory and planner)

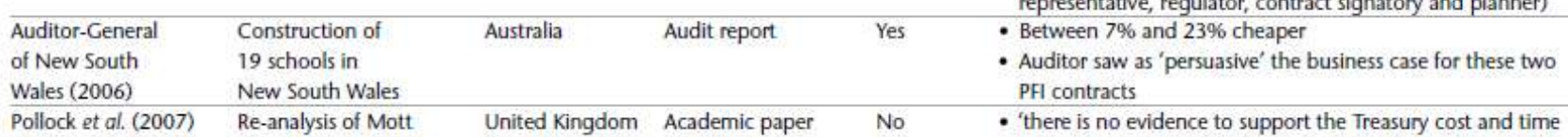

$\begin{array}{llll}\text { Pollock et al. (2007) } & \begin{array}{l}\text { Re-analysis of Mott } \\ \text { Macdonald and }\end{array} & \text { United Kingdom Academic paper } \quad \text { No } & \text { - 'there is no evidence to support the Treasury cost and time } \\ \text { overrun claims of improved efficiency in PFI'... [estimates }\end{array}$ other reports being quoted are] 'not evidence based but biased to favor PFI...'

- only one study compares PFI procurement performance, and 'all claims based on [this] are misleading'

\begin{tabular}{|c|c|c|c|c|c|}
\hline $\begin{array}{l}\text { Allen Consulting } \\
\text { Group (2007) }\end{array}$ & $\begin{array}{l}\text { Sample of } 21 \text { PpPs } \\
\text { and } 33 \text { traditional } \\
\text { projects }\end{array}$ & Australia & Consulting report & Yes & $\begin{array}{l}\text { - PPPs reported as being an } 11 \% \text { cheaper alternative to } \\
\text { traditional projects } \\
\text { - Research project funded by Australia's infrastructure suppliers }\end{array}$ \\
\hline $\begin{array}{l}\text { Blanc-Brude et al. } \\
\text { (2006) }\end{array}$ & $\begin{array}{l}227 \text { new road sections } \\
\text { across } 15 \text { EU countries, } \\
\text { of which } 65 \text { were PPPs }\end{array}$ & European Union & $\begin{array}{l}31 \text { regression } \\
\text { analyses }\end{array}$ & Not tested & $\begin{array}{l}\text { - Ex-ante construction costs of PPPs were } 24 \% \text { higher than } \\
\text { traditional procurement } \\
\text { - This is a similar magnitude to the traditional cost over-runs } \\
\text { - Whether PPPs deliver lower overall life-cycle costs remains } \\
\text { unknown }\end{array}$ \\
\hline $\begin{array}{l}\text { Leviakangas } \\
\text { (2007, p. 211) }\end{array}$ & $\begin{array}{l}\text { A Finnish toll-road } \\
\text { case study }\end{array}$ & Finland & Financial models & No & $\begin{array}{l}\text { - The hypothesis that private finance enabled welfare gains } \\
\text { to be achieved was not confirmed }\end{array}$ \\
\hline
\end{tabular}

Source: Graeme A. Hodge and CarstenGreve, 'PPPs: The Passage of Time Permits a Sober Reflection', iea economic affairs, March 2009, pp 33-39

Similarly, in the UK, the noticeable PPP failures have been the Metronet, HM Revenue \& Customs Estate, NHS and Housing. The National Audit Office (NAO) in the UK analyses in depth cases of public expenditure and levies appropriate fines for performance falling short of required standards. For example, Metronet had to pay a fine of $11 \mathrm{million}$ in April 2004 for poor performance Brief particulars these cases are available in Appendix I. All these events seemed to illustrate a key potential weakness of PPPs. When they involve essential infrastructure that government will not allow to fail, it is clear that a high proportion of a project's risk remains with the public sector.

\section{Conclusions}

Value for money in PPP projects should be seen as an important benchmark in evaluating PPP projects. For VFM to bring about good results, a lot of thinking has to go into setting up the criteria for its identification and measurement. Risk transfer is a key element and if this does not take place - such as the cases in UK where the government could not let the projects fail, - value for money cannot be achieved. Besides, estimates for the public sector comparator have to be thought of very carefully taking into account life cycle costing. This is an important learning for Governments and multilateral institutions in Asia where infrastructure development is being seen as crucial to maintain high growth rates.

\section{Appendix I}

\section{Private finance initiatives that failed the taxpayerin UK}

Although UK has been the most successful in the generation of PPP projects, the following cases that did not deliver the expected results also need to be studied in depth.

\section{Metronet}

The most spectacular private finance initiative failure was the collapse of Metronet in 2007. The deal between Metronet, Tube Lines and Transport for London (TfL) was put together in 2003 to upgrade London's creaking Underground network. In 2003 the Metronet consortium began a $£ 17$ billion project covering nine out of twelve tube lines. It soon got into difficulties. In April 2004, it was fined $£ 11$ million for poor performance, but this was just the start. Further fines followed and in June 2007, Metronet, concerned about cost escalation, requested an extraordinary review by the PPP Arbiter. A short-term cost overrun of $£ 551$ million was predicted, rising to $£ 2$ billion by 2010 , and this was blamed on additional demands made by Transport for London.

But the Arbiter had a different view - most of the cost escalation could be explained by Metronet's inefficiency and only a small fraction of the requested extra payments would be forthcoming. Faced with huge losses, the company went into 
administration. The government tried to find private bidders for the Metronet contracts but failed - unsurprisingly given the uncertainty concerning costs. The public sector then became responsible for the upgrades and maintenance. Taxpayers would now pick up the bill for any cost overruns. Within five years, the Metronet consortium collapsed, costing taxpayers £2bn as its functions were taken over by TfL.

\section{HM Revenue \& Customs estate}

The PAC concluded in April that the PFI deal covering ownership and management of 60 per cent of the HMRC's estate is also failing to deliver value for money. The 20-year deal signed by Mapeley Steps Contractor in 2001 has cost the taxpayer 20 per cent more than expected so far, the PAC said.

\section{NHS}

Latest estimates suggest that the NHS faces a £65bn bill for 103 new PFI hospitals with an estimated value of £11.3bn at the time they were built. The Government says the schemes provide value for money. But some trusts are now handing over more than 10 per cent of their annual turnover.

The inability of either conventional DBFO PFI or traditional NHS procurement processes to meet the majority of NHS capital requirements has prompted many commentators to argue that a new financing model is required that can bring together the benefits of both without the drawbacks of either. This may be summarised as a more flexible and scalable PFI. Scalability is key: the ability to provide efficient and manageable financing from unit and ward level right up to trust level. The considerable challenges faced by this new approach will include: unlocking the extensive value currently hidden in many trusts' assets; developing and modernising trust facilities, often on a unit by unit basis; and developing services that respond to changing patterns of usage and technology, both sensitively and flexibly.

\section{Housing}

According to the NAO, more than four-fifths of local authorities' 25 PFI housing projects are over budget. Nearly half are running at more than twice the anticipated cost (June 2010 report). And the average delay is two-and-a-half years.

The traditional approach to health service purchasing has tended to leave trusts with a bitter legacy of high maintenance costs, inconsistent support and ineffective replacement programmes. Financial data on the whole-life cost of assets tends to be fragmented, often held in different places, or is even simply not collected. As a result, it can be difficult for a trust to analyse and control the cost of their assets effectively.

Source: http://www.independent.co.uk/news/business/news/mod-aircraft-deal-worth-163105bn-failed-to-deliver2080408.html

\section{References}

Government of India, Ministry of Finance, Department of Economic Affairs (2010), "Approach Paper on Defining Public Private Partnerships, Discussion Note” (February) (http://www.pppinindia.com/pdf/ppp_definition_approach_paper.pdf)

Queensland Government (2008), "Public Private Partnerships Guidance Material"

(http://www.dip.qld.gov.au/resources/guideline/ppp-value-for-money-framework/1-overview-2008.pdf)

Report of Asian PPP Study Group, Ministry of Economy, Trade and Industry (2005), April (http://www.meti.go.jp/english/report/downloadfiles/AsianPPP.pdf)

Abdel Aziz, Ahmed M.(2007), "Successful Delivery of Public-Private Partnerships for Infrastructure Development", Journal of Construction Engineering \& Management, Vol. 133, Issue 12 (December): 918-931

Ball, Rob; King, David (2006), “The Private Finance Initiative in Local Government”, Economic Affairs, Vol. 26, Issue 1 (March): 36-40

Bing, Li; Akintoye, A.; Edwards, P. J.; Hardcastle, C. (2005), "The Allocation of Risk in PPP/PFI Construction Projects in the UK”, International Journal of Project Management, Vol. 23, Issue 1 (Jan): 25-35

Binza, Shakespeare Mzikayise (2008), "Public-Private Partnerships in Metropolitan Government: Perspectives on Governance, Value for Money and the Roles of Selected Stakeholders", Development Southern Africa, Vol. 25, Issue 3 (Sept): 297-315

Blanken, Anneloes; Dewulf, Geert (2010), “PPPs in Health: Static or Dynamic?”, Australian Journal of Public Administration, Supplement 1, Vol. 69 (March): S35-S47

Clifton, Chris; Duffield, Colin (2006), "Improved PFI/PPP Service Outcomes through the Integration of Alliance Principles", International Journal of Project Management, Vol. 24, Issue 7 (October): 573-586

Connolly, Ciaran; Reeves, Eoin; Wall, Anthony (2009), "Isomorphism: An Explanation for the Popularity of Public-Private Partnerships?", Irish Accounting Review, Vol. 16, Issue 1 (Summer): 1-1

Cutler, Peter (2004), “A Dose of Realism?”, Public Private Finance, Issue 81 (March): 18-18

Day, Karen; McHugh, Joseph (2000), “Tube Reports Puts PPP Plan in a Spin”, Public Finance, (29 Sept): 
Davis Langdon \& Everest (2000), "Cost Model", Building, (June): 1-6

(http://www.davislangdon.com/upload/StaticFiles/EME\%20Publications/CostModels/ValueForMoney_CM_30Jun00.pdf

Ed Farquharson, “UK's PPP Programme - Experience and Lessons Learned”, Partnerships UK Report

Fischer, Katrin; Jungbecker, Andrea; Alfen, Hans Wilhelm.(2006), "The Emergence of PPP Task Forces and their Influence on Project Delivery in Germany”, International Journal of Project Management, Vol. 24, Issue 7 (October): 539 547

Fredebeul-Krein, Markus; Knoben, Werner (2010), "Long-Term Risk Sharing Contracts as an Approach to Establish Public-Private Partnerships for Investment into Next Generation Access Networks", Telecommunications Policy, Vol. 34, Issue 9 (October): 528-539

Garvin, Michael J.; Bosso, Doran (2008), "Assessing the Effectiveness of Infrastructure Public-Private Partnership Programs and Projects", Public Works Management \& Policy, Vol. 13, Issue 2 (October): 162-178

Gavieta, Rommel C.(2008), "Global Lessons in Public Private Partnerships: Financing Policy Options to Mitigate Transport Project Risks in the Southeast Asian Region", Journal of Structured Finance, Vol. 14, Issue 1 (Spring): 65-72

Graeme A. Hodge and CarstenGreve (2009), “PPPs: The Passage of Time Permits a Sober Reflection”, iea economic affairs (March): 33-39

Grimsey, Darrin; Lewis, Mervyn K(2005), "Are Public Private Partnerships Value for Money? Evaluating Alternative Approaches and Comparing Academic and Practitioner Views", Accounting Forum, Vol. 29, Issue 4 (December): $345-378$ Harding, David (2002), “Now Departments Need to Prove Value for Money in PPPs”, Public Finance, 5/31: 10-13 Hellowell, Mark (2003), "Re-Appraising the Appraisal”, Public Private Finance, Issue 76 (September): 14-14 Hodge, Graeme A.; Greve, Carsten (2009), “PPPs: The Passage of Time Permits a Sober Reflection”, Economic Affairs, Vol. 29, Issue 1 (March): 33-39

Hood, John; Fraser, lan; McGarvey Neil (2006), "Transparency of Risk and Reward in U.K Public-Private Partnerships", Public Budgeting \& Finance, Vol. 26, Issue 4 (Winter): 40-58

Hood, John; McGarvey, Neil (2002), "Managing the Risks of Public-Private Partnerships in Scottish Local Government", Policy Studies, Vol.23, Issue 1(March): 21-35

Hurst, Claire; Reeves, Eoin (2004), “An Economic Analysis of Ireland's First Public Private Partnership", International Journal of Public Sector Management, Vol. 17, Issue 5: 379-388

Jacobson, Carol; Choi, Sang Ok (2008), "Success Factors: Public Works and Public-Private Partnerships", International Journal of Public Sector Management, Vol. 21, Issue 6: 637-657

Jefferies, Marcus; McGeorge, W. D. (2009), “Using Public-Private Partnerships (PPPs) to Procure Social Infrastructure in Australia”, Engineering Construction \& Architectural Management (09699988), Vol. 16, Issue 5: 415-437

Jingfeng Yuan; Yajun Zeng, Alex; Skibniewski, Miroslaw J.; Qiming Li. (2009), "Selection of Performance Objectives and Key Performance Indicators in Public-Private Partnership Projects to Achieve Value for Money", Construction Management \& Economics, Vol. 27, Issue 3 (March): 253-270

Jin, Xiao-Hua; Doloi, Hemanta (2008), "Interpreting Risk Allocation Mechanism in Public-Private Partnership Projects: An Empirical Study in a Transaction Cost Economics Perspective", Construction Management \& Economics, Vol. 26, Issue 7 (July): 707-721

Jones, Doug (2002), "PPPs in Australia: Removing the Government Blinkers”, PFI Report, Issue 65 (July): 24

Klijn, Erik-Hans (2009), "Public-Private Partnerships in the Netherlands: Policy, Projects and Lessons", Economic Affairs, Vol. 29, Issue 1(March): 26-32

Koppenjan, J. F. M.(2005), "The Formation of Public-Private Partnerships: Lessons from Nine Transport Infrastructure Projects in the Netherlands", Public Administration, Vol. 83, Issue 1 (March): 135-157

Morallos, Dorothy; Amekudzi, Adjo (2008), "The State of the Practice of Value for Money Analysis in Comparing Public Private Partnerships to Traditional Procurements", Public Works Management \& Policy, Vol. 13, Issue 2 (October):114125

Ng, S. Thomas; JingzhuXie; Kumaraswamy, Mohan M. (2010), "Simulating the Effect of Risks on Equity Return for Concession-Based Public-Private Partnership Projects", Engineering Construction \& Architectural Management (09699988), 2010, Vol. 17, Issue 4: 352-368

Nisar, Tahir M.(2007), "Value for Money Drivers in Public Private Partnership Schemes", International Journal of Public Sector Management, Vol. 20, Issue 2: 147-156

Nisar, Tahir (2007), "Risk Management in Public-Private Partnership Contracts", Public Organization Review, Vol. 7, Issue 1 (March): 1-19 
Philippe Burger and lan Hawkesworth (2010), "How to Attain Value for Money: omparing PPP and Traditional Infrastructure Public Procurement”, Annual OECD network meeting of Senior PPP Officials in Paris 12-13 April

Raisbeck, Peter (2008), "Perceptions of Architectural Design and Project Risk: Understanding the Architect's Role in a PPP Project”, Construction Management \& Economics, Vol. 26, Issue 11 (November): 114-115

Reeves, Eoin; Ryan, James (2007), "Piloting Public-Private Partnerships: Expensive Lessons from Ireland's Schools", Public Money\& Management, Nov2007, Vol. 27, Issue 5 (November): 331-338

Reside Jr., Renato E.(2009), "Global Determinants of Stress and Risk in Public-Private Partnerships (PPP) in Infrastructure", Journal of International Business Research, Vol. 8 Supplement 2, (June): 43-59

Robinson, Herbert S.; Scott, Jon.(2009), "Service Delivery and Performance Monitoring in PFI/PPP Projects", Construction Management \& Economics, Vol. 27, Issue 2 (February): 181-197

Roumboutsos, Athena; Anagnostopoulos, Konstantinos P.(2008), "Public-Private Partnership Projects in Greece: Risk Ranking and Preferred Risk Allocation", Construction Management \& Economics, Vol. 26, Issue 7 (July): 751-763

Shaoul, Jean (2002), "A Financial Appraisal of the London Underground Public-Private Partnership", Public Money\& Management, Vol. 22, Issue 2 (June): 53

Sobhiyah, M.H.; Bemanian, M.R.; Kashtiban, Y.Kh. (2009), "Increasing VFM in PPP Power Station Projects - Case Study: Rudeshur Gas Turbine Power Station", International Journal of Project Management, Vol. 27, Issue 5 (July): 512-521

Startin, Jonathan; Baxter, Adrian; Harding, Nick (2009), “Comparing Public-Private Partnerships for Highway Projects in the USA and the UK/EU", Journal of Public Works \& Infrastructure, Vol. 1, Issue 4 (March): 329-348

Tang, LiYaning; Shen, Qiping; Cheng, Eddie W.L. (2010), "A Review of Studies on Public-Private Partnership Projects in the Construction Industry", International Journal of Project Management, Vol. 28, Issue 7 (October): 683-694

Torres, Lourdes; Pina, Vicente (2001), "Public-Private Partnership and Private Finance Initiatives in the EU and Spanish Local Governments", European Accounting Review, Vol. 10, Issue 3 (Sept): 601-619

Tranfield, D.; Rowe, A.; Smart, P.K.; Levene, R.; Deasley, P.; Corley, J. (2005), "Coordinating for Service Delivery in Public-Private Partnership and Private Finance Initiative Construction Projects: Early Findings from an Exploratory Study", Proceedings of the Institution of Mechanical Engineers -- Part B -- Engineering Manufacture, Vol. 219, Issue 1(Jan): 165175

Wibowo, Andreas; Mohamed, Sherif (2010), "Risk Criticality and Allocation in Privatised Water Supply Projects in Indonesia", International Journal of Project Management, Vol. 28, Issue 5 (July): 504-513

Xiao-Hua Jin (2010), "Determinants of Efficient Risk Allocation in Privately Financed Public Infrastructure Projects in Australia", Journal of Construction Engineering \& Management, Vol. 136 Issue 2 (February): 138-150

Zhang, Xueqing (2005), "Paving the Way for Public-Private Partnerships in Infrastructure Development", Journal of Construction Engineering \& Management, Vol. 131, Issue 1 (January), p71-80

Zitron, Jeff (2006), "Public-Private Partnership Projects: Towards a Model of Contractor Bidding Decision-Making", Journal of Purchasing \& Supply Management, Vol. 12, Issue 2 (March): 53-62

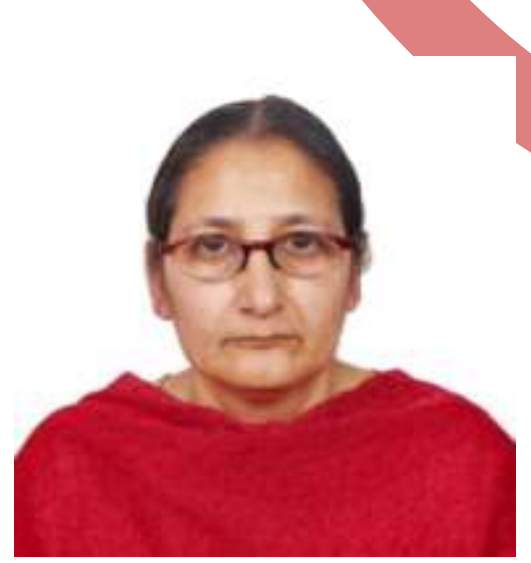

Dr (Mrs) Satinder Bhatia is Professor (Finance) and Chairperson (International Collaborations and Capacity Development) at the Indian Institute of Foreign Trade, New Delhi, India. She has held key responsibility and leadership positions at the Institute steering the Institute to new directions. The visionary measures undertaken have helped the Institute to markedly increase the portfolio of programmes on offer at the Institute. As Professor (Finance), Dr Bhatia has taught a range of finance subjects - Financial Management, Financial \& Managerial Accounting, Equity Market Analysis, Bond Market Analysis, Fixed Income Securities, Project Appraisal \& Finance, Technical Analysis, Cost Management Strategies and Financial Strategies. Earlier, she has written a book on 'Cost of Capital \& Corporate Policy'. She also has a number of research papers to her credit. Her current research interests deal with issues relating to international accounting. 